\title{
Korelasi Disiplin Kerja dan Motivasi Kerja dengan Kinerja Guru di Sekolah Dasar
}

\section{A. A. Gde Ananda Kusuma ${ }^{1}$, I Gusti Agung Oka Negara ${ }^{2}$}

1,2 Pendidikan Dasar, Universitas Pendidikan Ganesha, Singaraja, Indonesia

\section{A R T I C L E I N F 0}

Article history

Received June 14, 2021

Revised June 17, 2021

Accepted September 21, 2021

Available online October 25, 2021

Kata Kunci:

Motivasi, Disiplin, Kinerja Guru

Keywords:

Motivation, Discipline, Teacher Performance

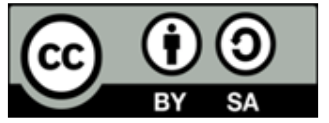

This is an open access article under the CC BY-SA license.

Copyright $(2021$ by Author. Published by Universitas Pendidikan Ganesha.

\begin{abstract}
A B S T R A K
Penelitian ini bertujuan untuk mengetahui hubungan motivasi kerja dan disiplin kerja terhadap kinerja guru. Jenis penelitian ini adalah penelitian ex-post facto. Populasi penelitian ini adalah seluruh guru PNS sebanyak 32 orang. Teknik pengambilan sampel dilakukan dengan teknik sampling total dengan menggunakan keseluruhan populasi yang dijadikan sampel yaitu sebanyak 32 guru PNS. Pengumpulan data pada penelitian ini dilakukan dengan metode dengan kuesioner untuk mengumpulkan data tentang variabel motivasi kerja dan disiplin kerja, sedangkan data vaiabel kinerja guru dikumpulkan dengan pencatatan dokumen. Data yang diperoleh kemudian dianalisis menggunakan statistika deskriptif dan statistika inferensial. Pada pengujian hipotesis menggunakan uji regresi sederhana untuk hipotesis I, II, dan menggunakan uji regresi ganda untuk hipotesis III. Hasil penelitian menunjukkan bahwa terdapat hubungan yang signifikan antara motivasi kerja dan kinerja guru dengan kontribusi sebesar $11,78 \%$; terdapat hubungan yang signifikan disiplin kerja dan kinerja guru dengan kontribusi sebesar 44,5\%; terdapat hubungan yang signifikan antara motivasi kerja dan disiplin kerja dengan kinerja guru dengan kontribusi sebesar $56,28 \%$, sehingga dapat disimpulkan bahwa terdapat hubungan yang signifikan antara motivasi kerja dan disiplin kerja dengan kinerja guru.
\end{abstract}

\section{A B S T R A C T}

This study aims to determine the relationship between work motivation and work discipline on teacher performance. This type of research is ex-post facto research. The population of this study were all PNS teachers as many as 32 PNS teachers. The sampling technique was carried out using a total sampling technique using the entire population as samples, namely as many as 32 PNS teachers. Data collection in this study was carried out using a questionnaire method to collect data on work motivation and work discipline variables, while teacher performance variables were collected by recording documents. The data obtained were then analyzed using descriptive statistics and inferential statistics. In testing the hypothesis using simple regression test for hypotheses I, II and using multiple regression test for hypothesis III. The results showed that there was a significant relationship between work motivation and teacher performance with a contribution of $11.78 \%$; there is a significant relationship between work discipline and teacher performance with a contribution of $44.5 \%$; there is a significant relationship between work motivation and work discipline with teacher performance with a contribution of $56.28 \%$, so it can be concluded that there is a significant relationship between work motivation and work discipline with teacher performance.

\section{PENDAHULUAN}

Perkembangan zaman yang semakin maju menuntut adanya umber daya manusia (SDM) yang berkualitas. SDM yang berkualitas merupakan modal utama untuk mencapai tujuan pembangunan. Salah satu wahana untuk meningkatkan kualitas SDM tersebut adalah pendidikan. Proses pendidikan secara formal dilaksanakan di sekolah dengan adanya interaksi antara guru dan siswa dalam kegiatan pembelajaran (Haruna, 2021; Ismail et al., 2018). Sekolah merupakan tempat penyelenggaraan kegiatan pendidikan berlangsung. Keberhasilan sekolah tidak dapat terlepas dari peran guru sebagai tenaga pendidik dalam menghasilkan SDM yang berkualitas. Pembelajaran yang berkualitas dapat diwujudkan oleh guru yang memiliki kemampuan dan motivasi yang tinggi dalam melaksanakan kewajiban (Julaeha, 
2019; Mizal \& Hidayani, 2018). Guru berperan penting dalam mentransfer ilmu pengetahuan dan teknologi yang dimilikinya kepada peserta didik melalui kegiatan pembelajaran (Hartini, 2019; Rahmawati \& Suryadi, 2019; Sopandi, 2019).

Kemampuan dan motivasi guru dalam mempersiapkan peserta didiknya melalui kegiatan belajar mengajar harus senantiasa ditingkatkan agar tujuan pendidikan dapat tercapai. Guru sebagai salah satu faktor penentu keberhasilan tujuan pendidikan dituntut memiliki kinerja yang mampu merealisasikan harapan dan keinginan semua pihak terutama masyarakat umum yang telah mempercayai sekolah dalam membina peserta didik. Kinerja guru adalah kemampuan dan usaha guru untuk melaksanakan tugas (Putra \& Negara, 2021). Guru yang memiliki kinerja baik, memenuhi beberapa kompetensi seperti kompetensi pedagogik, kompetensi kepribadian, kompetensi sosial dan kompetensi profesional yang diperoleh melalui pendidikan profesi (Hasan, 2017; Rahayu et al., 2020). Upaya untuk meningkatkan kinerja dalam rangka mencapai tujuan pendidikan bukan merupakan hal yang tidak mungkin untuk dilakukan. Salah satu upaya yang dapat dilakukan adalah dengan pemberian motivasi (Ginanjar, 2018; Wulandari \& Renda, 2020). Pemberian motivasi yang tepat diharapkan dapat mendorong guru untuk meningkatkan kinerjanya. Selain memacu guru untuk tidak mudah puas dengan hasil kerja yang telah dicapainya, guru juga terdorong untuk lebih produktif sehingga menghasilkan kinerja yang maksimal (Akbar, 2018; Baharudin, 2017)

Di sisi lain, kedisiplinan kerja guru penting untuk diperhatikan karena keberhasilan pendidikan banyak berharap dari guru. Kinerja guru yang baik tidak dapat dicapai jika tidak disertai dengan ketaatan guru pada peraturan-peraturan yang berlaku dalam melaksanakan pekerjaan. Pemeliharaan dan peningkatan kedisiplinan guru diharapkan dapat meningkatkan keefektifan kegiatan belajar mengajar dan selanjutnya dapat meningkatkan kinerja guru. Menjunjung tinggi kedisiplinan juga dapat menjadikan pandangan masyarakat lebih baik sehingga kepercayaan masyarakat terhadap sekolah tersebut dapat meningkat (Sukaimi, 2018; Rodi et al., 2020)

Namun, berdasarkan pra observasi pada proses pembelajaran di masa pandemi yang dilakukan di SDN Gugus I Tegallalang, terdapat beberapa masalah yang ditemui di antaranya kinerja guru rata-rata belum optimal terlihat dari tingkat absensi guru yang cukup tinggi berdasarkan rekapitulasi presensi guru dan kurang kreatif menggunakan metode pembelajaran. Hal ini sejalan dengan penelitiann (Ardiana, 2017; Sukayana, Yudana, \& Hendra Divayana, 2019) yang mengatakan bahwa dalam proses pembelajaran guru belum menggunakan RPP, kekurangan bahsan ajar serta menggunakan model dan metode pembelajaran yang monoton. Melaksanakan kegiatan belajar mengajarn secara daring dengan menggunakan metode pembelajaran yang tidak bervariasi mengakibatkan siswa menjadi malas atau bosan dalam mempelajari materi (Jundu, Jehadus, Nendi, Kurniawan, \& Men, 2019; Wijayanti \& Fauziah, 2020).

Setiap guru rata-rata tiga kali datang terlambat ke sekolah dalam seminggu. sehingga menimbulkan situasi yang kurang mendukung dalam proses pembelajaran. Kesadaran guru mengenai arti penting disiplin kerja dalam melaksanakan tugas-tugasnya juga masih rendah. Masalah ini timbul karena masih ada guru baru atau berusia muda yang meniru kebiasaan tidak disiplin yang dilakukan oleh guru yang telah lebih lama mengajar. Kebiasaan tidak baik seperti ini apabila sering dilakukan dapat mengganggu proses belajar mengajar dan secara otomatis menjadi contoh yang tidak baik pula bagi para siswa. Peraturan yang ada di sekolah juga belum optimal dalam mengatasi pelanggaran kedisiplinan karena kurangnya ketegasan dari kepala sekolah dalam menindak lanjuti pelanggaran yang terjadi. Masalah lain yang timbul adalah guru masih kurang terpacu dan termotivasi dalam memberdayakan dirinya untuk memaksimalkan potensi kreativitasnya. Padahal, apabila para guru memiliki kemauan dan bersedia memaksimalkan potensi kreativitasnya dapat memberikan pengaruh yang baik juga terhadap kinerjanya dan peningkatan karirnya.

Dari hasil observasi yang dilaksanakan, terlihat ketidaksesuaian dalam hal kedisiplinan guru dalam melaksanakan kinerjanya pada proses pembelajaran jarak jauh di masa pandemi. Hal ini dipengaruhi oleh banyak faktor dan akibat ketidaksiapan guru dalam melaksanakan perubahan dalam proses pembelajaran konvensional ke pembelajaran jarak jauh. Kendala yang dirasakan oleh guru dalam proses pembelajaran jarak jauh adalah tidak semua guru menguasi IPTEK dengan baik sebagai sarana dan media pembelajaran jarak jauh. Dampak lain yang dirasakan guru akibat sekolah diliburkan membuat rasa jenuh. Guru kehilangan jiwa sosialnya karena tidak berinteraksi dengan rekan sejawatnya di sekolah. Hal ini menyebabkan guru kehilangan motivasi dalam melakukan kinerjanya selama proses pembelajaran jarak jauh berlangsung (Primasari \& Zulela, 2021; Lubis, 2020).

Berdasarkan permasalahan, diketahui bahwa kinerja dipengaruhi oleh beberapa faktor yaitu kemampuan guru, motivasi, dan disiplin kerja. Berdasarkan uraian di atas perlu dilakukan penelitian mengenai hubungan disiplin kerja dan motivasi kerja dengan kinerja guru. Penelitian sejenis sebelumnya mengenai pengaruh disiplin kerja dan motivasi kerja terhadap kinerja guru memperoleh hasil terdapat 
pengaruh yang signifikan secara simultan disiplin kerja dan motivasi kerja terhadap kinerja guru (Astuti, 2017). Keterbaharuan penelitian ini adalah dilaksanakan pada masa pandemi disaat sekolah sedang melakukan pembelajaran jarak jauh. Berbeda dengan penelitian sebelumnya yang dilaksanakan pada tahun 2017 disaat sekolah masih mengadakan pembelajaran secara tatap muka. Penelitian sejenis lainnya mengenai pengaruh disiplin kerja dan motivasi kerja terhadap kinerja guru yang memperoleh hasil terdapat pengaruh yang signifikan disiplin kerja dan motivasi kerja terhadap kinerja guru (Alhusaini, Keitiawan, \& Eddy, 2020). Keterbaharuan penelitian ini dapat memberikan informasi pengaruh disiplin kerja dan motivasi kerja terhadap kinerja guru pada jenjang pendidikan SD.

Tujuan penelitian ini adalah untuk mengetahui korelasi dan kontribusi disiplin kerja dan motivasi kerja terhadap kinerja guru. Motivasi dan disiplin kerja dapat mendukung baik tidaknya kinerja guru dalam proses pembelajara. Oleh karean itu, kedisiplinan dan kinerja guru berguna untuk meningkatkan kualitas proses pelaksanaan pembelajaran di sekolah.

\section{METODE}

Penelitian ini tergolong dalam penelitian noneksperimen (ex post facto) dengan jenis studi korelasional. Penelitian ini menggunakan dua variabel bebas dan satu variabel terikat. Variabel bebas dalam penelitian ini adalah motivasi kerja dan disiplin kerja, sedangkan variabel terikat dalam penelitian ini adalah kinerja guru. Populasi dalam penelitian ini adalah seluruh guru PNS pada SD Negeri di Gugus I Tegallalang sebanyak 32 guru. Teknik pengambilan sampel pada penelitian ini menggunakan sampling total yaitu dengan mengambil keseluruhan populasi sabagai sampel penelitian yaitu sebanyak 32 guru PNS di SD Gugus I Tegallalang.

Metode pengumpulan data pada penelitian ini dengan menggunakan metode observasi dan kuesioner. Observasi dilakukan untuk mengamati fenomena yang sedang dijadikan sasaran. Sasaran yang diamati adalah perilaku guru yang berkaitan dengan motivasi kerja, disiplin kerja, dan kinerja guru. Kuesioner digunakan untuk memperoleh data tentang motivasi kerja, disiplin kerja, dan kinerja guru. Data kinerja guru merupakan data sekunder karena diperoleh dari data PKG tahun 2021. Data disiplin kerja dan motivasi kerja dalam penelitian ini merupakan data primer yang diungkap dengan menyebar atau memberikan angket kepada seluruh guru. Tabel 1 dan Tabel 2 menunjukkan kisi-kisi kuesioner yang digunakan untu mengukur disiplin kerja dan motivasi kerja guru.

Tabel 1. Kisi-Kisi Instrumen Variabel Motivasi Kerja

\begin{tabular}{|c|c|c|c|c|}
\hline \multirow{2}{*}{ No } & \multirow{2}{*}{ Indikator } & \multicolumn{2}{|c|}{ Nomor Butir } & \multirow{2}{*}{ Jumlah Butir } \\
\hline & & + & - & \\
\hline 1 & Kebutuhan akan prestasi & $1,2,3,4,5,6,7$ & - & 7 \\
\hline 2 & Kebutuhan akan pengakuan & $8,9,10,11,12,13,14$ & - & 7 \\
\hline 3 & Kebutuhan akan kekuasaan & $15,17,18,19,20$ & 16 & 6 \\
\hline \multicolumn{4}{|c|}{ Jumlah } & 20 \\
\hline
\end{tabular}

Tabel 2. Kisi-Kisi Instrument Variabel Disiplin Kerja

\begin{tabular}{llccc}
\hline \multirow{2}{*}{ No } & \multicolumn{1}{c}{ Indikator } & \multicolumn{2}{c}{ Nomor Butir } & \multirow{2}{*}{ Jumlah Butir } \\
\cline { 3 - 5 } & Ketepatan Waktu & $1,2,3,4,5,6,7$ & $8,9,10$ & 10 \\
\hline 1 & Ketaatan pada peraturan & $11,12,13,14,15,16,17$ & $18,19,20$ & 10 \\
\hline & & Jumlah & & $\mathbf{2 0}$ \\
\hline
\end{tabular}

Penelitian ini menggunakan metode analisis data statistik deskriptif dan statistik infrensial. Analisis deskriptif gunakan untuk mendeskripsikan data, dengan mencari mean, media, modus dan standar deviasi. Analisis statistik infensial digunakan untuk menganalisis data sampel dan hasilnya diberlakukan untuk populasi. Statistik inferensial yang digunakan dalam penelitian ini yaitu regresi sederhana dan uji regresi ganda. Sebelum melakukan uji hipotesis, terlebih dahulu dilakukan uji prasyarat analisis dengan menggunakan uji normalitas, uji linieritas, dan uji multikolinieritas. Jika sudah terpenuhi maka, selanjutnya dapat dilaksanakan uji hipotesis dengan teknik analisis regresi sederhana dan uji regresi ganda. 


\section{HASIL DAN PEMBAHASAN}

Hasil

Pencatatan dokumen untuk mendapatkan data kinerja guru yaitu digunakan dokumen penilaian kinerja guru (PKG) yang diperoleh dari masing-masing kepala sekolah yang ada di SD Gugus I Tegallalang. Data yang dikumpulkan dengan kuesioner untuk mendapatkan data motivasi kerja dan disiplin kerja guru di SD Gugus I Tegallalang. Berikut adalah hasil pengujian statistik deskriptif data kinerja guru, motivasi kerja dan disiplin kerja dalam penelitian ini disajikan pada Tabel 3.

Tabel 3. Hasil Perhitungan Statistik Deskriptif

\begin{tabular}{lccc}
\hline \multirow{2}{*}{ Data Statistik } & \multicolumn{3}{c}{ Variabel } \\
\cline { 2 - 4 } & Kinerja Guru & Motivasi Kerja & Disiplin Kerja \\
\hline Jumlah Sampel & 32,00 & 32,00 & 32,00 \\
Mean & 40,94 & 55,63 & 71,75 \\
Median & 42,50 & 58,50 & 74,00 \\
Modus & 38,00 & 60,00 & 80,00 \\
Standar Deviasi & 7,24 & 8,50 & 8,09 \\
Varians & 52,45 & 72,24 & 65,42 \\
Skor Minimum & 25,00 & 35,00 & 48,00 \\
Skor Maksimum & 50,00 & 75,00 & 80,00 \\
\hline
\end{tabular}

Sebelum melaksanakan pengujian hitopesis, terlebih dahulu dilaksanakan uji prasyarat. Uji prasyarat yang harus dilalui yaitu uji normalitas, uji linieritas dan uji multikolinieritas. Uji normalitas dilakukan untuk mengetahui apakah data berdistribusi normal atau tidak. Pada penelitian ini pengujian menggunakan uji Kolmogorov-Smirnov dianalisis menggunakan bantuan Microsoft Excel 2019 dengan membandingkan |FT - FS| dengan nilai tabel Kolmogorov - Smirnov (KS). Dengan taraf signifikansi 5\%, sehingga diperoleh tabel KS yaitu 0,156. Pengujian linieritas merupakan suatu teknik yang digunakan untuk mengetaui apakah ada hubungan linier antara variabel terikat dengan variabel bebas dalam sebuah penelitian. Pada penelitian ini, pengujian analisis menggunakan bantuan Microsoft Excel 2019 dengan taraf signifikansi $5 \%$.

Uji multikolinieritas digunakan untuk mengetahui apakah terdapat hubungan antar variabel bebas yang cukup tinggi. Apabila terdapat hubungan yang tinggi antar variabel bebas berarti ada aspek yang sama diukur pada variabel tersebut. Pengujian multikolinieritas dianalisis menggunakan bantuan IBM SPSS Statistic 21.0 dengan ketentuan jika nilai Tol $\leq 0,1$ atau nilai VIF $\geq 10$, maka dikatakan terjadi multikolinieritas. Sebaliknya jika nilai Tol $\geq 0,1$ atau nilai VIF $\leq 10$, maka dapat dikatakan tidak terjadi multikolinieritas. Tabel 6 menunjukkan penghitungan hasil uji multikolinieritas menggunakan IBM SPSS Statistic 21.0.

Tabel 6. Hasil Uji Multikolinieritas

\begin{tabular}{|c|c|c|c|c|c|c|c|c|}
\hline & \multirow{2}{*}{ Model } & \multicolumn{2}{|c|}{$\begin{array}{l}\text { Unstandardized } \\
\text { Coefficients }\end{array}$} & \multirow{2}{*}{$\begin{array}{c}\text { Standardize } \\
\text { d } \\
\text { Coefficients } \\
\text { Beta }\end{array}$} & \multirow{2}{*}{$\mathbf{t}$} & \multirow{2}{*}{ Sig. } & \multicolumn{2}{|c|}{$\begin{array}{l}\text { Collinearity } \\
\text { Statistics }\end{array}$} \\
\hline & & $\mathbf{B}$ & $\begin{array}{c}\text { Std. } \\
\text { Error }\end{array}$ & & & & Tolerance & VIF \\
\hline \multirow{3}{*}{1} & (Constant) & 39,900 & 17,034 & & 2,342 & 0,026 & & \\
\hline & Motivasi & 1,016 & 0,187 & 0,596 & 5,435 & 0,000 & 0,996 & 1,004 \\
\hline & Disiplin & 0,910 & 0,196 & 0,508 & 4,631 & 0,000 & 0,996 & 1,004 \\
\hline
\end{tabular}

Tabel 6 menunjukkan bahwa pada setiap variabel memiliki nilai Tolerance diatas 0,1 dan nilai VIF diatas 10, maka dapat dikatakan bahwa motivasi kerja dan disiplin kerja tidak terjadi multikolinieritas.

Uji prasyarat sudah terpenuhi maka selanjutnya dilakukan uji hipotesis. Pada penelitian ini terdapat tiga hipotesis. Pengujian hipotesis I dengan menggunakan analisis regresi sederhana dengan taraf signifikansi 0,05 diperoleh $F_{\text {hitung }}=13,9>F_{\text {tabel }}=4,25$ dengan taraf signifikansi 0,05 dk 1:30, maka garis regresi variabel motivasi kerja dengan kinerja guru signifikan. Hasil uji koefisien korelasi product moment pada taraf signifikansi $5 \%$ diperoleh $r_{\text {tabel }}=0,296$ dengan $\mathrm{dk}=30$. Maka dengan demikian $r_{\text {hitung }}=$ 0,303 $>r_{\text {tabel }}=0,296$ dapat dinyatakan bahwa adanya korelasi positif motivasi kerja dan kinerja guru. Hasil yang diperoleh menyatakan bahwa tingkat hubungan interval koefisien sedang. sehingga dapat diambil keputusan bahwa antara motivasi kerja dan kinerja guru terdapat hubungan yang signifikan. Dari hasil 
korelasi parsial diperoleh $R Y X_{1} X_{2}=0,1422$ yang kemudian dilakukan uji-t didapatkan nilai thitung = 3,311 dan nilai t-tabel $=2,022$ dengan taraf signifikansi 5\%, maka diperoleh thitung lebih besar dari pada ttabel yaitu 3,311 > 2,022, sehingga dapat dinyatakan bahwa antara motivasi kerja dan kinerja guru memiliki koefisien korelasi parsial yang signifikan.

Berdasarkan analisis koefisien determinasi motivasi kerja dengan kinerja guru diperoleh r2 = 0,0918 yang berarti bahwa motivasi kerja mempengaruhi kinerja guru dengan kontribusi sebesar 9,18\%. Pengujian selanjutnya dilakukan yaitu untuk mengetahui bobot sumbangan efektif (SE) yang diperoleh nilai sebesar $11,78 \%$. Dari analisis data dengan menggunakan regresi sederhana untuk penggujian hipotesis pertama dapat dinyatakan bahwa $\mathrm{HO}$ ditolak dan $\mathrm{H} \alpha$ diterima dengan bunyi "Terdapat korelasi yang signifikan antara motivasi kerja dan kinerja guru di SDN Gugus I Tegallalang tahun ajaran 2020/2021".

Pengujian hipotesis II dengan menggunakan analisis regresi sederhana dengan taraf signifikansi 0,05 diperoleh $F_{\text {hitung }}=14,849>\mathrm{F}_{\text {tabel }}=4,25$ dengan taraf signifikansi $0,05 \mathrm{dk}$ 1:30, maka garis regresi variabel disiplin kerja dengan kinerja guru signifikan. Hasil uji koefisien korelasi product moment pada taraf signifikansi 5\% diperoleh $r_{\text {tabel }}=0,296$ dengan $\mathrm{dk}=30$. Maka dengan demikian $r_{\text {hitung }}=0,882>r_{\text {tabel }}=$ 0,296 dapat dinyatakan bahwa adanya korelasi positif disiplin kerja dengan kinerja guru. Dari hasil yang diperoleh menyatakan tingkat hubungan interval koefisien kuat. sehingga dapat diambil keputusan bahwa antara disiplin kerja dengan kinerja guru terdapat hubungan yang signifikan. Dari hasil korelasi parsial diperoleh $R Y X_{1} X_{2}=0,733$ yang kemudian dilakukan uji-t didapatkan nilai thitung $=8,834$ dan nilai $t_{\text {tabel }}=$ 2,022 dengan taraf signifikansi 5\%, maka diperoleh thitung lebih besar dari pada tabel yaitu 8,834>2,022 sehingga dapat dinyatakan bahwa antara disiplin kerja dengan kinerja guru memiliki koefisien korelasi parsial yang signifikan.

Berdasarkan analisis koefisien determinasi disiplin kerja dengan kinerja guru diperoleh $\mathrm{r}^{2}=$ 0,779 yang berarti bahwa disiplin kerja mempengaruhi kinerja guru dengan kontribusi sebesar 77,9\%. Pengujian selanjutnya dilakukan yaitu untuk mencari tau bobot sumbangan efektif (SE) yang diperoleh nilai sebesar 44,5\%. Dari analisis data dengan menggunakan regresi sederhana untuk penggujian hipotesis kedua dapat dinyatakan bahwa $\mathrm{H}_{0}$ ditolak dan $\mathrm{H}_{\alpha}$ diterima dengan bunyi "terdapat hubungan yang signifikan antara disiplin kerja dengan kinerja guru di SD Gugus I Tegalalang tahun Ajaran 2020/2021".

Pengujian hipotesis III dengan menggunakan uji analisis regresi ganda pada taraf signifikansi 0,05 diperoleh $F_{\text {hitung }}=19,573>\mathrm{F}_{\text {tabel }}=4,25$ dengan taraf signifikansi 0,05 dk 2:29, maka garis regresi variabel motivasi kerja dan disiplin kerja terhadap kinerja guru signifikan. Hasil uji koefisien korelasi ganda pada taraf signifikansi 5\% diperoleh $\mathrm{r}_{\text {tabel }}=0,361$ dengan $\mathrm{dk}=30$. Maka dengan demikian $R_{\text {hitung }}=0,7502>\mathrm{r}_{\text {tabel }}$ = 0,296 dapat dinyatakan bahwa adanya korelasi positif motivasi kerja dan disiplin kerja dengan kinerja guru. Dari hasil yang diperoleh menyatakan tingkat hubungan interval koefisien kuat.

Berdasarkan analisis koefisien determinasi antara motivasi kerja dan disiplin kerja dengan kinerja guru diperoleh $\mathrm{R}^{2}=0,5628$ yang berarti bahwa motivasi kerja dan disiplin kerja mempengaruhi kinerja guru dengan kontribusi sebesar 56,28\%. Pengujian selanjutnya dilakukan yaitu untuk mencari tau bobot sumbangan efektif (SE) antara motivasi kerja dan disiplin kerja dengan kinerja guru memperoleh nilai sebesar 56,28\% dan 43,72\% dipengaruhi oleh faktor-faktor lain.

\section{Pembahasan}

Hasil penelitian menunjukkan bahwa motivasi kerja dan disiplin kerja memengaruhi kinerja guru. Motivasi kerja adalah penggerak atau pendorong dalam diri seseorang untuk mau berperilaku dan bekerja dengan giat dan sesuai dengan tugas dan kewajiban yang diberikan kepadanya (Saragih, Simarmata, \& Parulian, 2018; Yusuf \& Suci, 2018). Motivasi kerja bermanfaat sebagai pendorong bagi seseorang agar berusaha mencapai kinerja sesuai tugas yang diberikan. Teori kebutuhan dari McCleland menjelaskan halhal yang dapat memotivasi seseorang yaitu kebutuhan akan prestasi, kebutuhan akan afiliasi, dan kebutuhan akan kekuasaan (Maizahroh \& Ulum, 2020; Yusuf \& Suci, 2018). McCleland berpendapat bahwa karyawan mempunyai energi potensial. Energi digunakan bergantung pada kekuatan dorongan yang dimiliki seseorang dan situasi serta peluang yang tersedia. Guru yang memiliki motivasi tinggi diharapkan dapat bekerja secara maksimal dan berusaha untuk memberikan yang terbaik yang dapat dilakukan karena merupakan tuntutan profesinya. Jika motivasi kerja guru maksimal, maka diharapkan kinerja guru juga akan maksimal. Hasil penelitian ini juga senada dengan penelitian terdahulu yang dilakukan oleh (Segantara, Yudana, \& Sunu, 2018) yang menunjukkan bahwa terdapat hubungan positif dan signifikan antara motivasi kerja guru dengan kinerja guru. Faktor yang sangat membantu guru dalam meningkatkan kinerja guru adalah kompetensi profesional guru dan motivasi kerja (Putra \& Negara, 2021). Penelitian relevan menunjukkan bahwa terdapat pengaruh motivasi kerja terhadap kinerja guru Sekolah Dasar 
Negeri di Kecamatan Pagelaran Kabupaten Pringsewu. Faktor lainnya adalah disiplin kerja (Asterina \& Sukoco, 2019).

Disiplin kerja sebagai suatu sikap dan perilaku yang berniat untuk menaati segala peraturan organisasi yang didasarkan atas kesadaran diri untuk menyesuaikan dengan peraturan organisasi (Fauzi \& Malini, 2020). Beberapa indikator disiplin kerja yang dapat dijadikan sebagai ukuran kedisiplinan yaitu ketepatan waktu meliputi ketepatan jam pulang, ketepatan jam masuk, kepatuhan pada jam kerja; kesetiaan atau patuh pada peraturan atau tata tertib yang ada, meliputi kepatuhan untuk memakai seragam dan kepatuhan terhadap peraturan dan komitmen yang telah disepakati; mempergunakan dan memelihara peralatan kantor. Disiplin kerja guru merupakan hal penting yang harus senantiasa dipelihara karena diharapkan dapat memperlancar kegiatan sekolah. Jika disiplin kerja guru baik maka diharapkan semakin tinggi pula kinerja yang dicapai (Suryani, Sahono, \& Somantri, 2017). Hasil penelitian ini juga senada dengan penelitian terdahulu (Utari \& Rasto, 2019). Penelitian tersebut menunjukkan bahwa terdapat hubungan positif dan signifikan antara disiplin kerja dan kinerja guru. Penelitian lain menunjukkan bahwa terdapat pengaruh disiplin guru terhadap kinerja guru (Asterina \& Sukoco, 2019).

Penilaian kinerja guru bermanfaat bagi sekolah yaitu dalam hal penyesuaian-penyesuaian kompensasi personel sekolah, perbaikan kinerja personel sekolah, kebutuhan latihan dan pengembangan personel sekolah, pengambilan keputusan dalam hal penempatan, promosi, mutasi, pemecatan, pemberhentian, dan perencanaan personel baru, dan penelitian personel sekolah, serta membantu diagnosis terhadap kesalahan desain personel sekolah (Ritonga, 2019; Maizahroh \& Ulum, 2020). Berdasarkan pendapat tersebut menunjukkan bahwa melalui penilaian kinerja guru diharapkan dapat mewujudkan kinerja yang lebih baik. Kinerja guru yang lebih baik akan mendorong tercapainya tujuan pendidikan yang berkualitas. Motivasi kerja dan disiplin kerja guru harus selalu ditingkatkan karena diharapkan dapat meningkatkan kinerja guru. Jika motivasi kerja dan disiplin kerja guru semakin baik maka diharapkan semakin tinggi pula kinerja guru yang dicapai. Hasil penelitian ini juga senada dengan penelitian terdahulu yang menunjukkan bahwa terdapat hubungan positif dan signifikan antara motivasi dan disiplin kerja secara bersama-sama dengan kinerja guru (Wijania, 2017; Alhusaini et al., 2020). Penelitian serupa menunjukkan bahwa terdapat pengaruh kepemimpinan kepala sekolah, motivasi kerja dan disiplin kerja terhadap kinerja guru (Gea \& Tarigan, 2013).

Hasil penelitian ini ditujukan kepada guru dan kepala sekolah. Dari penelitian ini, diharapkan guru akan mampu meningkatkan motivasi kerja dan disiplin kerja, sehingga kualitas dari kinerja guru dapat meningkat dan mutu pendidikan di Indonesia juga meningkat. Peningkatan yang terjadi pada kinerja guru tidak hanya dirasakan oleh guru itu sendiri, tetapi akan disarakan oleh seluruh warga sekolah. Pentingnya seorang guru dalam memiliki motivasi kerja dan disiplin kerja yang tinggi akan memberikan dampak positif dalam kehidupan. Selain itu implikasi bagi kepala sekolah yaitu diharapkan dapat dijadikan sebagai acuan dalam memberikan masukan sehingga kepala sekolah mampu menjadi motivator yang baik untuk para guru disekolah dalam meningkatkan motivasi kerja dan disiplin kerja sehingga kinerja guru dapat meningkat. Dengan meningkatnya kinerja yang dimiliki seorang guru, kualitas dan mutu pendidikan juga dapat menjadi lebih optimal.

\section{SIMPULAN}

Berdasarkan hasil penelitian dan pembahasan yang dilakukan, maka dapat disimpulkan bahwa terdapat hubungan yang positif dan signifikan antara motivasi kerja dan disiplin kerja dengan kinerja guru di SDN Gugus 1 Tegalalang. Dengan demikan, dapat dikatakan bahwa semakin tinggi disiplin kerja dan motivasi kerja guru, maka semakin tinggi kualitas kinerja guru. Direkomendasikan kepada guru hendaknya memiliki disiplin diri dan motivasi yang tinggi dalam menjalankan tugas-tugas pendidikan, sehingga dapat mencapai hasil kinerja yang makasimal. Kinerja guru yang baik dapat meningkatkan kualitas proses pembelajaran.

\section{DAFTAR RUJUKAN}

Akbar, S. (2018). Analisa Faktor-Faktor yang Memengaruhi Kerja. Jurnal Jiaganis, 3(2), 1-17. http://jurnal.stiaindragiri.ac.id/site/index.php/jiaganis/article/view/52.

Alhusaini, A., Keitiawan, M., \& Eddy, S. (2020). Pengaruh Motivasi Kerja Dan Disiplin Kerja terhadap Kinerja Guru. Jurnal Pendidikan Tambusai, 4(3), 2166-2172. https://doi.org/10.31004/jptam.v4i3.693.

Ardiana, T. E. (2017). Pengaruh Motivasi Kerja Guru Terhadap Kinerja Guru Akuntansi SMK di Kota Madiun. Jurnal Akuntansi Dan Pajak, 17(2), 14-23. https://doi.org/10.29040/jap.v17i02.11.

Asterina, F., \& Sukoco. (2019). Pengaruh Kepemimpinan Kepala Sekolah, Motivasi Kerja dan Disiplin Guru terhadap Kinerja Guru. Jurnal Akuntabilitas Manajemen Pendidikan, 7(2). 
https://doi.org/10.21831/jamp.v7i2.26743.

Astuti, A. D. (2017). Pengaruh Motivasi dan Disiplin Kerja terhadap Kinerja Guru SD di Kabupaten Cilacap. $\begin{array}{llll}\text { Jurnal Akuntabilitas } & \text { Manajemen }\end{array}$ https://doi.org/10.21831/amp.v5i2.13931.

Baharudin, H. (2017). Peningkatan Kompetensi Guru melalui Sistem Kepemimpinan Kepala Madrasah. Jurnal Ilmu Tarbiyah At-Tajdid, 6(1), 1-26.

Fauzi, F., \& Malini. (2020). Determinasi Pelatihan dan Disiplin Kerja terhadap Kinerja Guru di SMPN 4 Takengon. Al-Idarah: Jurnal Kependidikan Islam, 10(2), 1-11. https://doi.org/https://doi.org/10.24042/alidarah.v10i2.6793.

Gea, K., \& Tarigan, U. (2013). Analisis Hubungan Kepemimpinan Kepala Sekolah, Motivasi, dan Disiplin Kerja terhadap Kinerja Guru SMA Negeri di Kabupaten Nias UtaraNo Title. Jurnal Administrasi Publik, 3(2). https://doi.org/10.31289/jap.v3i2.1351.

Ginanjar, A. (2018). Model Pembelajaran Taktis dan Motivasi Belajar terhadap Kebugaran Jasmani Siswa SMK. Jurnal Kependidikan, 2(2), 409-419. https://doi.org/10.21831/jk.v2i2.10746.

Hartini, S. (2019). Kompetensi Profesional Guru dalam Meningkatkan Motif Berprestasi Peserta Didik: Studi di SDN Karangpucung 04 dan SDN Karangpucung 05 Kabupaten Cilacap. Indonesian Journal of Educaton Management and Administration Review, 3(1), 1-6. https://jurnal.unigal.ac.id/index.php/ijemar/article/view/2949.

Haruna, J. (2021). Optimalisasi Pelayanan dan Motivasi Kerja dengan Kedisiplinan Pegawai dalam Mengukur Kepuasan Kinerja. BEduManageRs Journal, 2(1), 50-61. https://jurnal.fkip.unmul.ac.id/index.php/bedu/article/view/607.

Hasan, M. (2017). Pengaruh Kompetensi Profesional Guru terhadap Kinerja Guru Ekonomi Sekolah Menengah Atas Negeri di Kabupaten Gowa. Jurnal Economix, 5(2), 72-73. http://ojs.unm.ac.id/economix/article/download/5347/3087.

Ismail, Sulistyarini, \& Imran. (2018). Peran Pimpinan Memotivasi Bawah Melanjutkan Pendidikan S2 di Lingkungan Kerja Pemerintah Kecamatan Se-Kota Pontianak. Jurnal Pendidikan Dan Pembelajaran Khatulistiwa, 7(2), 1-8. https://jurnal.untan.ac.id/index.php/jpdpb/article/view/23837.

Julaeha, S. (2019). Problematika Kurikulum dan Pembelajaran Pendidikan Karakter. Jurnal Penelitian Pendidikan Islam, 7(2). https://doi.org/https://doi.org/10.36667/jppi.v7i2.367.

Jundu, R., Jehadus, E., Nendi, F., Kurniawan, Y., \& Men, F. E. (2019). Optimalisasi Media Pembelajaran Interaktif dalam Meningkatkan Kemampuan Matematis Anak di Desa Popo Kabupaten Manggarai. E-Dimas: Jurnal Pengabdian Kepada Masyarakat, 10(2), 221. https://doi.org/10.26877/edimas.v10i2.3353.

Lubis, W. (2020). Analisis Efektivitas Belajar pada Pembelajaran Jarak Jauh (Pjj) di Masa Pandemi Covid19. Jurnal Pendidikan Bahasa Dan Sastra Indonesia, 5(1), 139-140. https: //jurnal.uisu.ac.id/index.php/Bahastra/article/view/3282.

Maizahroh, \& Ulum, R. (2020). Pengaruh Faktor-Faktor Motivasi Kerja terhadap Kinerja Guru di SMA Darul Mustofa Tunjung Burneh Bangkalan, 4(1), 27-34. http://publikasi.stkippgribkl.ac.id/index.php/ECS/article/download/403/299/.

Primasari, I. F. N. D., \& Zulela. (2021). Kendala Pembelajaran Jarak Jauh (PJJ) secara Online Selama Masa Pandemik Covid-19 di Sekolah Dasar. JIKAP PGSD: Jurnal Ilmiah Ilmu Kependidikan, 5(1), 64-73. https://doi.org/10.26858/jkp.v5i1.16820.

Putra, I. W. A., \& Negara, I. G. A. O. (2021). Kontribusi Kompetensi Profesional Guru dan Motivasi Kerja terhadap Kinerja Guru SD. Jurnal Imiah Pendidikan Dan Pembelajaran, 5(1), 95-104. https://doi.org/10.23887/jipp.v5i1.32253.

Rahayu, M., Yuniarsih, T., Disman, Sojanah, J., Nusannas, I. S., \& Mutmainnah, D. (2020). Strategi Kepemimpinan Kepala Sekolah dalam Meningkatkan Kedisiplinan Guru pada Man 1 Kabupaten Aceh Utara. Jurnal Visipena, 99-115. https://doi.org/https://doi.org/10.46244/visipena.v11i2.1216.

Rahmawati, M., \& Suryadi, E. (2019). Guru sebagai Fasilitator dan Efektivitas Belajar Siswa. Jurnal Pendidikan Manajemen Perkantoran, 4(1), 49. https://doi.org/10.17509/jpm.v4i1.14954.

Ritonga, E. Y. (2019). Pentingnya Penilaian Prestasi Kerja dalam Organisasi. Jurnal Al-Idarah, 7(1), $13-35$. https://doi.org/http://dx.doi.org/10.37064/ai.v7i1.7546.

Rodi, M., Oktafiah, Y., \& Wahyudi, P. (2020). Pengaruh Kedisiplinan dan Fasilitas Kerja terhadap Kinerja Guru (Studi pada SMKN 1 Grati). Jurnal EMA, 4(2), 70-80. https://doi.org/10.47335/ema.v4i2.40.

Saragih, R. S., Simarmata, H. M., \& Parulian. (2018). Kepemimpinan, Kepuasan Kerja dan Motivasi terhadap Kinerja Pegawai. Jurnal Ilmiah Manajemen Dan Bisnis, 19(2), 124-133. https://doi.org/10.30596/jimb.v19i2.2146.

Segantara, I. G. M., Yudana, I. M., \& Sunu, I. G. K. A. (2018). Studi Korelasi antara Motivasi Kerja, 
Kompetensi Profesional Guru, dan Etos Kerja terhadap Kinerja Guru. Jurnal Penelitian Dan Pengembangan Sains Dan Humaniora, 1(1), 29-34. https://doi.org/10.23887/jppsh.v1i1.12927.

Sopandi, A. (2019). Pengaruh Kompetensi Profesional dan Kompetensi Kepribadian terhadap Kinerja Guru. Scientific Journal of Reflection, 2(2), 121-130. https://doi.org/10.5281/zenodo.2628070.

Sukaimi, S. dan M. S. H. (2018). Budaya Disiplin Kerja. Mandania, 8(2), $228-255$. https://doi.org/http://dx.doi.org/10.24014/jiik.v8i2.5729.

Sukayana, I. W., Yudana, M., \& Hendra Divayana, D. G. (2019). Kontribusi Kepemimpinan Transformasional, Supervisi Akademik Kepala Sekolah, Kompetensi Pedagogik dan Motivasi Kerja terhadap Kinerja Guru di SMK Kertha Wisata Denpasar. Jurnal Administrasi Pendidikan Indonesia, 10(2), 157-162. https://doi.org/10.23887/japi.v10i2.2804.

Suryani, L., Sahono, B., \& Somantri, M. (2017). Korelasi Kepemimpinan Kepala Sekolah dan Disiplin Antara Guru terhadap Kinerja Guru di SMP. Jurnal Manajer Pendidikan, 11(3), 233-238. https://ejournal.unib.ac.id/index.php/manajerpendidikan/article/view/3252.

Utari, K. T., \& Rasto, R. (2019). Pengaruh Disiplin Kerja terhadap Kinerja Guru. Jurnal Pendidikan Manajemen Perkantoran, 4(2), 246-253. https://doi.org/10.17509/jpm.v4i2.18019

Wijania, I. W. (2017). Kontribusi Kepemimpinan Pelayan Kepala Sekolah, Motivasi Kerja dan Disiplin Kerja terhadap Kinerja Guru. Jurnal Ilmiah Pendidikan Dan Pembelajaran, 1(3), 176-184. https: //ejournal.undiksha.ac.id/index.php/JIPP/article/view/11983.

Wijayanti, R. M., \& Fauziah, P. Y. (2020). Perspektif dan Peran Orangtua dalam Program PJJ Masa Pandemi Covid-19 di PAUD. Jurnal Obsesi: Jurnal Pendidikan Anak Usia Dini, 5(2), 1304-1312. https://doi.org/10.31004/obsesi.v5i2.768.

Wulandari, A. P., \& Renda, N. T. (2020). Hubungan antara Pola Asuh Orang Tua dan Motivasi Belajar Matematika Siswa. Mimbar Ilmu, 25(2), 90. https://doi.org/10.23887/mi.v25i2.26068.

Yusuf, T., \& Suci, G. (2018). Pengaruh Kompetensi Profesional Guru, Motivasi Kerja, dan Disiplin Kerja terhadap Kinerja Guru SMK Negeri 2 Penajam Paser Utara. Jurnal GeoEkonomi, 9(2), 117-132. https://doi.org/10.36277/geoekonomi.v9i2.23. 